\title{
Occupational neutrophilic asthma
}

\author{
Richard Leigh MBChB FCPSA, Frederick E Hargreave MD FRCP FRCPC \\ Asthma Research Group, Department of Medicine, St Joseph's Hospital and \\ McMaster University, Hamilton, Ontario
}

R Leigh, FE Hargreave. Occupational neutrophilic asthma. Can Respir J 1999;6(2):194-196.

Occupational asthma is typically associated with an eosinophilic bronchitis. The case of a 41-year-old woman who developed symptoms of asthma after occupational exposure to metal working fluids is reported. The diagnosis of asthma was confirmed by an forced expiratory volume in $1 \mathrm{~s}\left(\mathrm{FEV}_{1}\right)$ of 1.7 (59\% predicted), with $11 \%$ reversibility after inhaled bronchodilator and a provocation concentration of methacholine to cause a fall in $\mathrm{FEV}_{1}$ of $20 \%\left(\mathrm{PC}_{20}\right)$ of $0.4 \mathrm{mg} / \mathrm{mL}$. Induced sputum examination showed a marked neutrophilia. Over the next six months, serial sputum analyses confirmed the presence of a marked sterile neutrophilic bronchitis during periods of occupational exposure to metal working fluids, which resolved when the patient was away from work and recurred when she returned to work. The sputum findings were mirrored by corresponding changes in spirometry and $\mathrm{PC}_{20}$ methacholine. The findings indicate the occurrence of occupational asthma associated with an intense, sterile neutrophilic bronchitis after exposure to metal working fluids.

Key Words: Metal working fluids, Occupational asthma, Sputum

\begin{abstract}
Asthme à neutrophiles d'origine professionnelle
RÉSUMÉ : L'asthme professionnel est typiquement associé à une bronchite à éosinophiles. Le cas d'une femme de 41 ans qui a développé des symptômes d'asthme après une exposition professionnelle à des liquides utilisés pour le travail des métaux est rapporté. Le diagnostic d'asthme a été confirmé par un volume expiratoire maximum/seconde (VEMS) de 1,7 (59\% de la valeur théorique), avec une réversibilité de $11 \%$ après l'administration d'un bronchodilatateur en inhalation, et par une concentration de provocation à la méthacoline entraînant une chute du VEMS de 20 $\%\left(\mathrm{CP}_{20}\right)$ de $0,4 \mathrm{mg} / \mathrm{mL}$. Un examen de l'expectoration provoquée a révélé une importante neutrophilie. Au cours des six mois suivants, les analyses en série de l'expectoration ont confirmé la présence d'une importante bronchite à neutrophiles stérile, pendant les périodes d'exposition professionnelle aux liquides utilisés pour le travail des métaux, et qui se dissipait lorsque la patiente quittait son milieu de travail et récidivait lorsqu'elle y retournait. Les constatations concernant l'expectoration reflétaient des

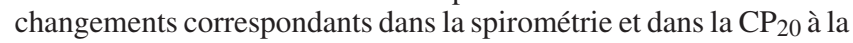
méthacholine. Ces résultats révèlent le développement d'un asthme professionnel associé à une importante bronchite à neutrophiles stérile après une exposition à des liquides utilisés pour le travail des métaux.
\end{abstract}

$\mathrm{O}$ ccupational asthma describes asthma caused by exposure to an agent found in the workplace, and is usually recognized in association with hypersensitivity to allergens or specific chemical sensitizers (1). The introduction of reliable methods to measure inflammatory cells by using induced sputum examination has made it possible to examine airway inflammation directly in a relatively noninvasive way (2). The use of sputum cell counts has shown the occurrence of different types of airway inflammation due to different causes. An eosinophilic inflammatory response, with or without asthma, is seen with airway reactions to allergens and occupational chemical sensitizers $(1,3)$, whereas neutrophilic inflammatory responses are seen in patients with smokers' bronchitis (2), smoking-related chronic airflow limitation (4) or infective bronchitis (5). In this report, we describe a newly recognized entity of an intense neutrophilic bronchitis with occupational asthma in a patient exposed to metal working fluids. 
TABLE 1

Patient characteristics in relation to work in a case of suspected occupational neutrophilic asthma

\begin{tabular}{|c|c|c|c|c|c|c|}
\hline $\begin{array}{l}\text { Patient } \\
\text { characteristics }\end{array}$ & $\begin{array}{c}\text { Normal } \\
\text { values }\end{array}$ & $\begin{array}{c}\text { At work } \\
\text { (three months) }\end{array}$ & $\begin{array}{c}\text { Off work } \\
\text { (four weeks) }\end{array}$ & $\begin{array}{c}\text { At work } \\
\text { (four weeks) }\end{array}$ & $\begin{array}{c}\text { Off work } \\
\text { (four weeks) }\end{array}$ & $\begin{array}{c}\text { Off work } \\
\text { (three months) }\end{array}$ \\
\hline Symptoms & - & +++ & + & +++ & + & - \\
\hline $\mathrm{FEV}_{1}(\mathrm{~L})$ & 2.9 & 1.7 & 3.0 & 2.3 & 2.6 & 2.9 \\
\hline Vital capacity (L) & 3.4 & 2.5 & 4.1 & 3.5 & 3.5 & 3.9 \\
\hline $\begin{array}{l}\mathrm{PC}_{20} \mathrm{mg} / \mathrm{mL} \\
\text { Induced sputum }\end{array}$ & $>16$ & 0.4 & 3.0 & 0.4 & 0.7 & 3.2 \\
\hline Colour & $M$ & MP & M & MP & MP & M \\
\hline Cell viability (\%) & $>40 \%$ & 80 & 80 & 85 & 82 & 83 \\
\hline Total cell count $\left(10^{6} / \mathrm{mg}\right)$ & $<5.5$ & 89 & 4.7 & 42 & 22 & 4.3 \\
\hline Neutrophils (\%) & $<35$ & 82 & 63 & 85 & 82 & 56 \\
\hline Eosinophils (\%) & $<2$ & 0 & 0.5 & 0.5 & 0.8 & 0.3 \\
\hline Macrophages (\%) & $<65$ & 17 & 35 & 13 & 13 & 40 \\
\hline Lymphocytes (\%) & $<2.5$ & 0.5 & 2 & 1 & 2 & 2 \\
\hline
\end{tabular}

Symptoms: +++ Severe; + Mild; - Absent. M Mucoid; MP Muco-purulent; PC 20 Provocation concentration of methacholine to cause a fall in forced expiratory volume in $1 \mathrm{~s}\left(F E V_{1}\right)$ of $20 \%$

\section{CASE PRESENTATION}

A woman, aged 41 years, was seen for assessment of possible occupational asthma. She had first noted the onset of intermittent dyspnea, chest tightness, wheezing and nonproductive cough two and a half years previously, shortly after starting a new job. She noted that her symptoms were initially worse after several hours at work, and improved substantially over weekends and during vacations. However, over time, her symptoms became progressively worse to the point where dyspnea limited her on exertion and woke her at night. In addition, her cough began to produce small amounts of mucopurulent sputum. Her symptoms did not improve despite a course of antibiotic, but she did obtain clinical benefit from inhaled salbutamol.

There was no past history of asthma or atopy and no other relevant medical history. There was no family history of allergies or asthma. Her current job was factory machinist assembling automobile parts, a position that was associated with continual exposure to a mist of industrial metal working fluids. She was not exposed to any recognized occupational sensitizers. Several co-workers within her immediate working environment also had respiratory symptoms. She had a 15 pack-year smoking history but had quit six months before when her symptoms became worse.

On clinical examination, she was apyrexial and appeared to be generally well, although there were diffuse expiratory wheezes present on chest auscultation. The remainder of the physical examination was normal.

Spirometry showed moderate airflow limitation (forced expiratory volume in $1 \mathrm{~s}$ [FEV 1$] 1.7 \mathrm{~L}, 59 \%$ predicted, Table 1 ), with $11 \%$ reversibility after inhaled salbutamol. A methacholine inhalation test (6) showed a moderate increase in airway responsiveness (provocation concentration of methacholine to cause a fall in $\mathrm{FEV}_{1}$ of $20 \% \quad\left[\mathrm{PC}_{20}\right]$ $0.4 \mathrm{mg} / \mathrm{mL}$, Table 1). Allergy skin prick tests with 19 common allergen extracts were negative, and a chest radiograph showed no abnormality. Blood leukocyte and differential cell counts were normal. Induced sputum was mucopurulent, and cell counts indicated an intense neutrophilic bronchitis without eosinophilia (Table 1). Sputum culture for respiratory pathogens showed only commensal organisms. Treatment with a 10-day course of oral clarithromycin was ineffective. The patient was advised to use inhaled salbutamol as required, and, in the absence of sputum eosinophilia, inhaled corticosteroids were not prescribed.

Over the next six months, the patient was seen in the clinic at regular intervals, during periods at and off work (Table 1). Spirometry showed variable airflow limitation. She had an intense sputum neutrophilia during periods at work, which was markedly attenuated two or more weeks after being off work, and recurred within two weeks of her return to work. Sputum bacterial, fungal and mycobacterial cultures on four occasions of intense neutrophilic bronchitis did not reveal any pathogens, and serological tests for mycoplasma and chlamydia were negative. Two additional courses of antibiotics did not result in clinical improvement. Microbiological culture of the metal working fluid was completed on two occasions and was negative for bacteria, fungi or mycobacteria.

A clinical diagnosis of occupational asthma, probably secondary to metal working fluid exposure, was made. No alternative relocation at work was possible, and the patient was advised to remain away from work. A compensation claim was initiated.

\section{DISCUSSION}

This case report provides insights into the inflammatory nature of airway disease gained from induced sputum examination in clinical practice, and identifies an association between an intense neutrophilic bronchitis and asthma in circumstances suggesting an occupational cause.

Sputum neutrophilia may have been predicted from the mucopurulent appearance of the sputum (7), but the intensity of the neutrophilia and the absence of an eosinophilia could not have been predicted. The recognition of these features de- 
pended on the examination of sputum by new reliable methods (2). The intensity of the neutrophilia was suggestive of a bacterial infection. However, no pathogenic organisms were cultured from repeated specimens, and no benefit was obtained from usually appropriate antibiotic treatment.

The sputum neutrophilia was associated with asthma as defined by variable airflow limitation and airway hyperresponsiveness. The association of asthma exacerbations with neutrophilia and without an eosinophilia has been increasingly recognized in influenza (5), exacerbations of varying severity $(8,9)$ and fatal asthma (10). The mechanisms by which neutrophilia is associated with exacerbations warrant investigation.

In the present case, sputum neutrophilia and exacerbations of asthma were convincingly associated with the patient being at work. The most likely cause was exposure to the metal working fluids (11-13). The fluid is known to contain respiratory irritants and not uncommonly become infected with bacteria or fungi $(12,13)$. In the present case, the Medical Safety Data Sheet indicated that the metal working fluid contained alkanolamine borate, sulphurized fatty acid ester, sodium petroleum sulfonate, fatty acid alkanolamine,

\section{REFERENCES}

1. Chan-Yeung M, Malo JL. Occupational asthma. N Engl J Med 1995;333:107-12.

2. Pizzichini E, Pizzichini MMM, Efthimiadis A, et al. Indices of airway inflammation in induced sputum: reproducibility and validity of cell and fluid phase measurements. Am J Respir Crit Care Med 1996;154:308-17.

3. Lemière C, Efthimiadis A, Hargreave FE. Occupational eosinophilic bronchitis without asthma: an unknown occupational airway disease. J Allergy Clin Immunol 1997;100:852-3.

4. Keatings VM, Barnes PJ. Granulocyte activation markers in induced sputum: comparison between chronic obstructive pulmonary disease, asthma, and normal subjects. Am J Respir Crit Care Med 1997; 155:449-53

5. Pizzichini MM, Pizzichini E, Efthimiadis A, et al. Asthma and natural colds. Inflammatory indices in induced sputum: a feasibility study. Am J Respir Crit Care Med 1998;158:1178-84.

6. Juniper EF, Cockcroft DW, Hargreave FE. Histamine and methacholine inhalation tests: a laboratory tidal breathing protocol. Lund: AB Draco, 1994.

7. Berlyne GS, Efthimiadis A, Hussack P, et al. Macroscopic versus microscopic sputum analysis in asthma. Eur Respir J 1997;10(Suppl 25):184s. (Abst) triethanolamine, ethylenediamine-tetra-acetic acid salt, alkyl phenol ethoxylate and a triazine biocide. These compounds are either acids or strong oxidizing agents and can cause respiratory 'irritation'. There were no documented sensitizers. Endotoxin can be produced as a result of bacterial contamination; while this is known to cause neutrophilic airway inflammation (14), contamination was not confirmed in the present case.

Exposure to mists of metal working fluids has been noted to cause industrial bronchitis, occupational asthma and hypersensitivity pneumonitis (12). However, the inflammatory response in relation to the causal agent(s) has not been examined. The present case report indicates a need to investigate the inflammatory effects of occupational exposures in relation to the clinical consequences in more detail. This is now facilitated by the use of induced sputum examination.

ACKNOWLEDGEMENTS: We thank Denise O'Shaughnessy for performing the spirometry and methacholine inhalation tests, and Ann Efthimiadis, Sharon Weston and Sue Carruthers-Elliott for performing the sputum cell counts.

8. Fahy JV, Kim KW, Liu J, Boushey HA. Prominent neutrophilic inflammation in sputum from subjects with asthma exacerbation. J Allergy Clin Immunol 1995;95:843-52.

9. Turner MO, Hussack P, Sears MR, Dolovich J, Hargreave FE. Exacerbations of asthma without sputum eosinophilia. Thorax 1995;50:1057-61.

10. Carroll N, Carello S, Cooke C, James A. Airway structure and inflammatory cells in fatal attacks of asthma. Eur Respir J 1996;9:709-15.

11. Kennedy SM, Chan-Yeung M, Teschke K, Karlen B. Change in airway responsiveness among apprentices exposed to metalworking fluids. Am J Respir Crit Care Med 1999; 159:87-93.

12. Zacharisen MC, Kadambi AR, Schlueter DP, et al. The spectrum of respiratory disease associated with exposure to metal working fluids. J Occup Environ Med 1998;40:640-7.

13. Rosenman KD, Reilly MJ, Kalinowski D. Work-related asthma and respiratory symptoms among workers exposed to metal-working fluids. Am J Ind Med 1997;32:325-31.

14. Nightingale JA, Rogers DF, Hart LA, Kharitonov SA, Chung KF, Barnes PJ. Effect of inhaled endotoxin on induced sputum in normal, atopic, and atopic asthmatic subjects. Thorax 1998;53:563-71. 


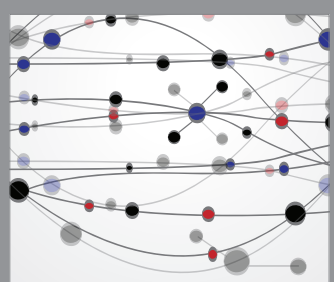

The Scientific World Journal
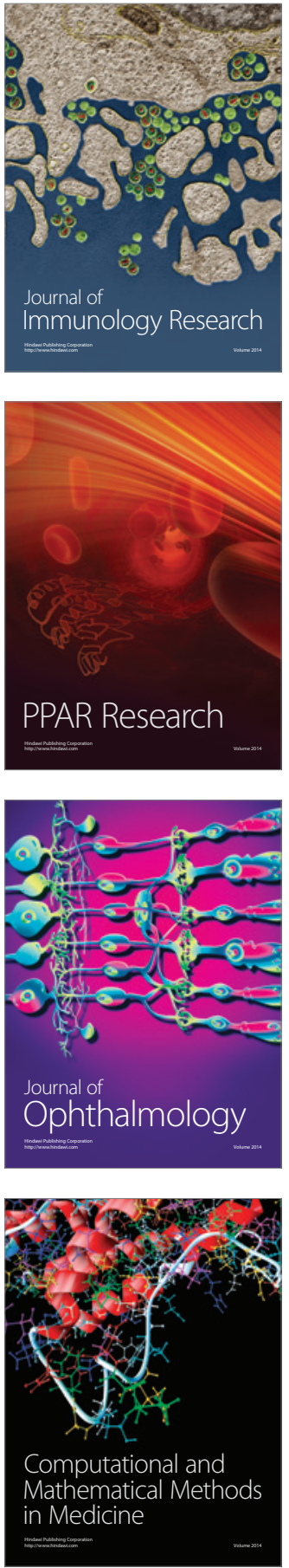

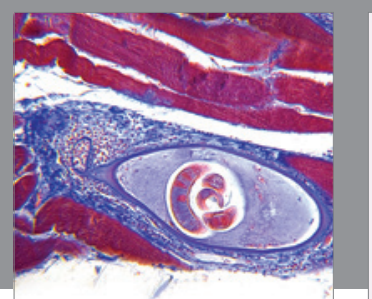

Gastroenterology Research and Practice

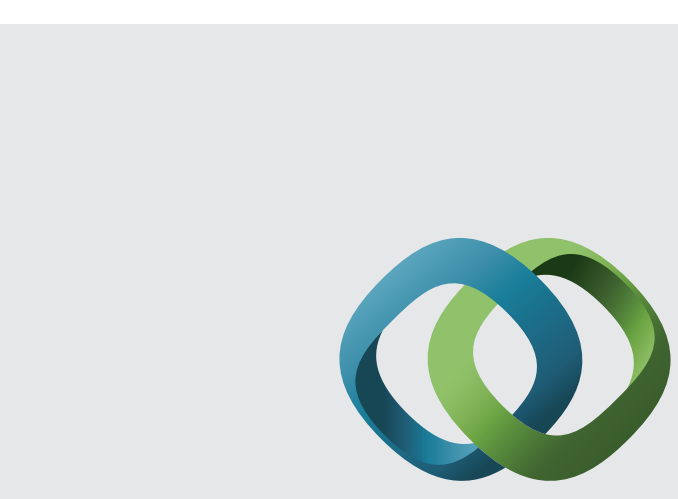

\section{Hindawi}

Submit your manuscripts at

http://www.hindawi.com
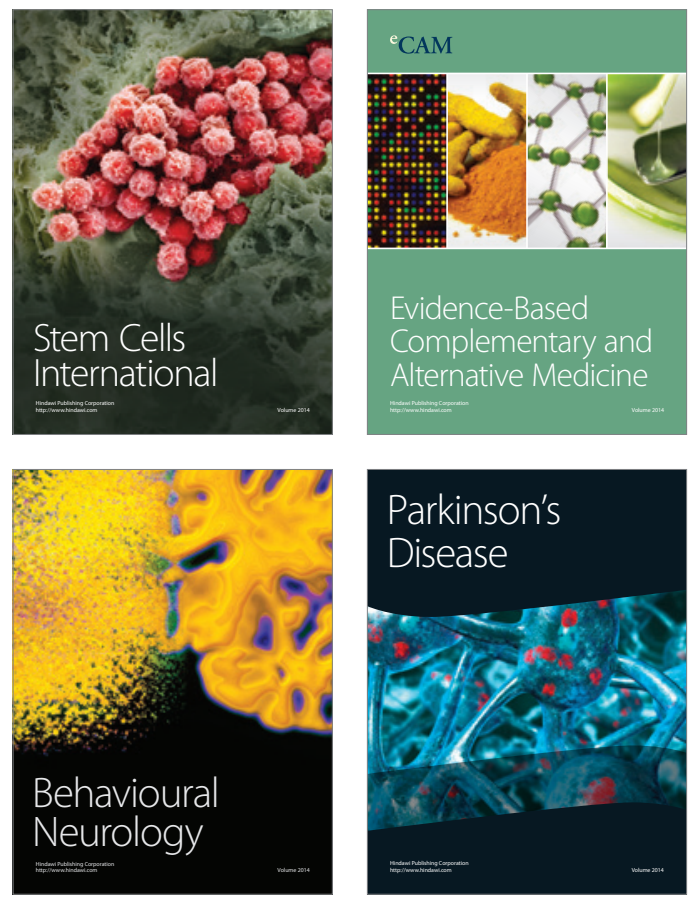
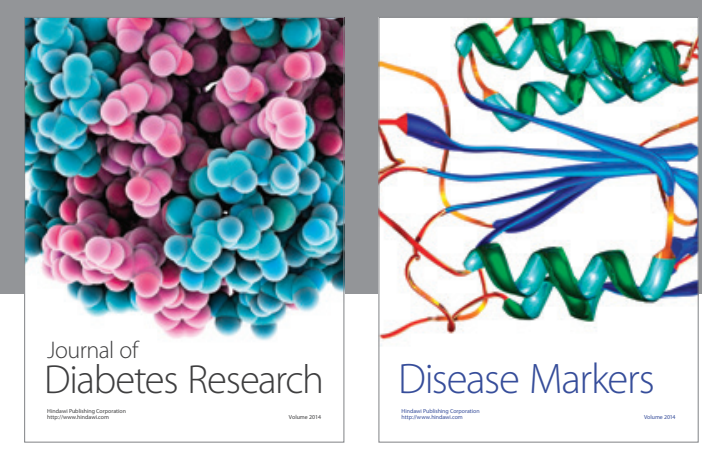

Disease Markers
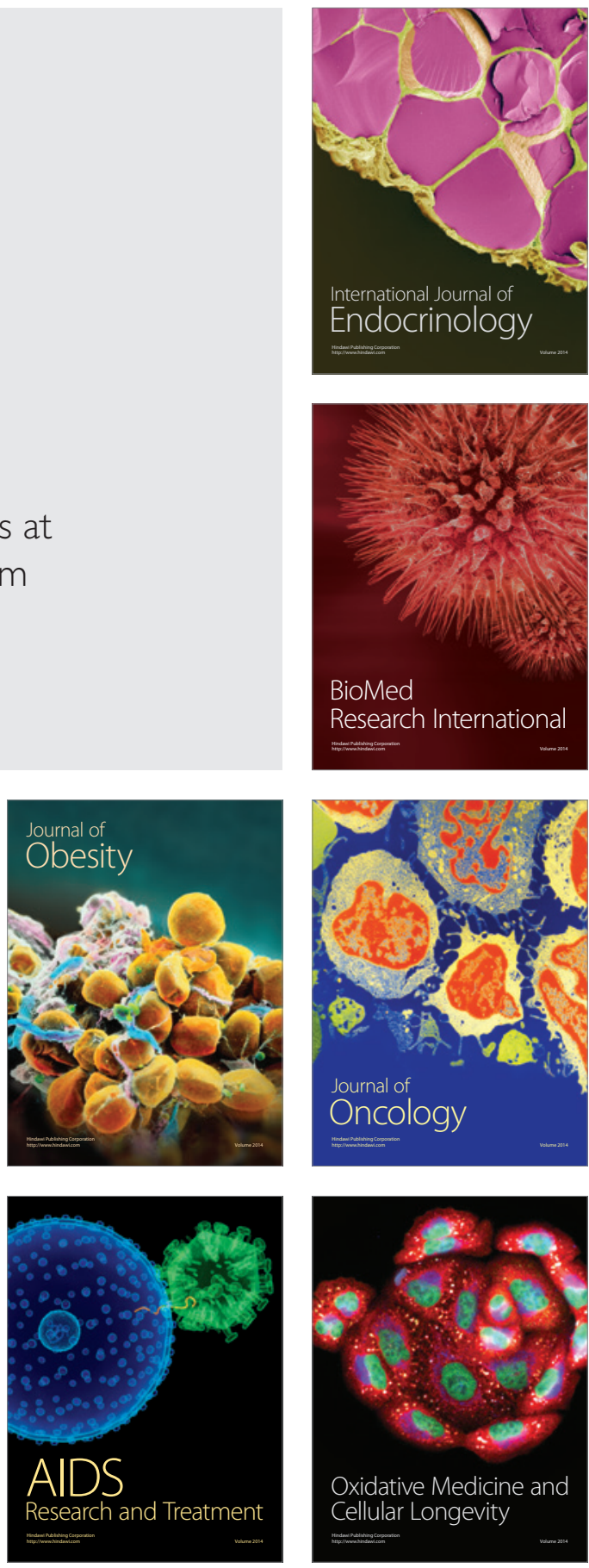